\title{
In-gel digestion coupled with mass spectrometry (GeLC-MS/MS)-based salivary proteomic profiling of canine oral tumors
}

\author{
Sekkarin Ploypetch ${ }^{1,2}$, Sittiruk Roytrakul ${ }^{3}$, Narumon Phaonakrop ${ }^{3}$, Suthathip Kittisenachai ${ }^{3}$, Kantinan Leetanasaksakul ${ }^{3}$,
} Sirinun Pisamai ${ }^{4}$, Chanin Kalpravidh ${ }^{4}$, Anudep Rungsipipat ${ }^{2,5}$ and Gunnaporn Suriyaphol ${ }^{1,2^{*}}$ (D)

\begin{abstract}
Background: Various types of oral tumors, either benign or malignant, are commonly found in dogs. Since saliva directly contacts the tumors and saliva collection is non-invasive, easily accessible and cost effective, salivary biomarkers are practical to be used for the diagnosis and/or prognosis of these diseases. However, there is limited knowledge of protein expression in saliva for canine oral tumors. The present study aimed to investigate novel biomarkers from the salivary proteome of dogs with early- and late-stage oral melanoma (EOM and LOM, respectively), oral squamous cell carcinoma (OSCC), benign oral tumors (BN), and periodontitis and healthy controls (CP), using an in-gel digestion coupled with mass spectrometry (GeLC-MS/MS). The relationships between protein candidates and chemotherapy drugs were explored and the expression of potential biomarkers in saliva and tissues was verified by western blot analysis.
\end{abstract}

Results: For saliva samples, increased expression of protein tyrosine phosphatase non-receptor type 5 (PTPN5) was shown in all tumor groups compared with the CP group. Marked expression of PTPN5 was also observed in LOM and OSCC compared with that in BN and EOM. In addition, tumor protein p53 (p53), which appeared in the PTPN5-drug interactions, was exhibited to be expressed in all tumor groups compared with that in the CP group. For tissue samples, increased expression of p53 was shown in LOM compared with the control group.

Conclusion: PTPN5 and p53 were proposed to be potential salivary biomarkers of canine oral tumors.

Keywords: Dog, In-gel digestion coupled with mass spectrometry (GeLC-MS/MS), Oral tumors, Tumor protein p53 (p53), Protein tyrosine phosphatase non-receptor type 5 (PTPN5)

\section{Background}

Head and neck tumors comprise approximately $7 \%$ of all tumors in dogs. Among these, oral melanoma (OM) and oral squamous cell carcinoma (OSCC) are most commonly found [1]. The tumor, node and metastasis (TNM) classification of

\footnotetext{
*Correspondence: Gunnaporn.V@chula.ac.th

'Biochemistry Unit, Department of Physiology, Faculty of Veterinary Science, Chulalongkorn University, 39 Henri-Dunant Road, Wangmai, Pathumwan, Bangkok 10330, Thailand

${ }^{2}$ Companion Animal Cancer Research Unit, Faculty of Veterinary Science, Chulalongkorn University, 39 Henri-Dunant Road, Wangmai, Pathumwan, Bangkok 10330, Thailand

Full list of author information is available at the end of the article
}

tumors in the oral cavity are described. Stages I and II refer to tumors with $\leq 2 \mathrm{~cm}$ and 2 to $<4 \mathrm{~cm}$, respectively, defined as early clinical stages with no metastasis, whereas stage III refers to a tumor with $\geq 4 \mathrm{~cm}$ and/or lymph node metastasis and stage IV refers to a tumor with distant metastasis. The latter two are defined as late clinical stages and are most frequently observed in the animal hospital owing to the difficulty in routinely examining tumors in dogs' mouths [2-4]. After surgical resection, patients with late clinical stage are normally treated with chemotherapy drugs such as carboplatin, a derivative of the anticancer drug cisplatin, doxorubicin (or Adriamycin ${ }^{\circ}$ ), cyclophosphamide and piroxicam. With a high rate of

(C) The Author(s). 2020 Open Access This article is licensed under a Creative Commons Attribution 4.0 International License, which permits use, sharing, adaptation, distribution and reproduction in any medium or format, as long as you give appropriate credit to the original author(s) and the source, provide a link to the Creative Commons licence, and indicate if changes were made. The images or other third party material in this article are included in the article's Creative Commons licence, unless indicated otherwise in a credit line to the material. If material is not included in the article's Creative Commons licence and your intended use is not permitted by statutory regulation or exceeds the permitted use, you will need to obtain permission directly from the copyright holder. To view a copy of this licence, visit http://creativecommons.org/licenses/by/4.0/ The Creative Commons Public Domain Dedication waiver (http://creativecommons.org/publicdomain/zero/1.0/) applies to the data made available in this article, unless otherwise stated in a credit line to the data. 
metastasis and recurrence of oral cancer, novel biomarkers are important for early clinical diagnosis, screening and prognosis of the diseases [5]. Saliva proteins have high potential to be appropriate biomarkers because saliva makes direct contact with an oral mass, and saliva collection is non-invasive and not difficult to manipulate [6]. Novel salivary proteome biomarkers have been discovered in human oral tumors [7-10]. However, in dogs with oral diseases, the evidence of proteomics in saliva is still limited [6]. The present study aimed to search for novel suitable biomarkers in saliva of dogs with early- and late-stage oral melanoma (EOM and LOM, respectively), oral squamous cell carcinoma (OSCC), benign oral tumors $(\mathrm{BN})$, periodontitis $(\mathrm{P})$ and healthy controls $(\mathrm{C})$ (CP group), using in-gel digestion coupled with mass spectrometry (GeLC-MS/MS). Associations of disease-related proteins with the chemotherapy drugs cisplatin, cyclophosphamide, piroxicam and doxorubicin were exhibited. The candidate protein expressions in saliva and tissues were affirmed by western blot analysis.

\section{Results}

\section{GeLC-MS/MS results}

A total of 3726 proteins were identified. The distribution of the individual and overlapped proteins in $\mathrm{EOM}, \mathrm{LOM}, \mathrm{OSCC}, \mathrm{BN}$ and $\mathrm{CP}$ groups was illustrated by a Venn diagram (Fig. 1). In addition, the molecular function, biological process, cellular component and the relative expression levels of the proteins uniquely expressed in each group and commonly expressed in all cancerous groups was analysed using the PANTHER software tools (Tables 1 and 2 and Supplementary Table S1). For the networks of protein-protein and protein-chemotherapy drug interactions, analysed by the Stitch program, version 5.0, edge confidence scores demonstrated the strength of the interactions at the functional level. Pathways with high edge confidence scores $(>0.700)$ were presented as thick lines. The associations of protein tyrosine phosphatase non-receptor type 5 (PTPN5) and tumor protein p53 (p53) with cisplatin and doxorubicin drugs were shown. Additionally, the correlation of PTPN5 and cyclophosphamide was demonstrated (Fig. 2). In the present study, increased expression of another protein involved in the SUMOylation process, RanBP2, was noted in a cancerous group (Table 2). RanBP2 regulated translocation of p53, a well-known target of SUMOylation, to the cytoplasm, leading to poor prognosis and prostate cancer progression [11].

\section{Western blot analysis results}

Western blot analysis unveiled an enhanced expression of PTPN5 and p53 in saliva of tumor groups compared

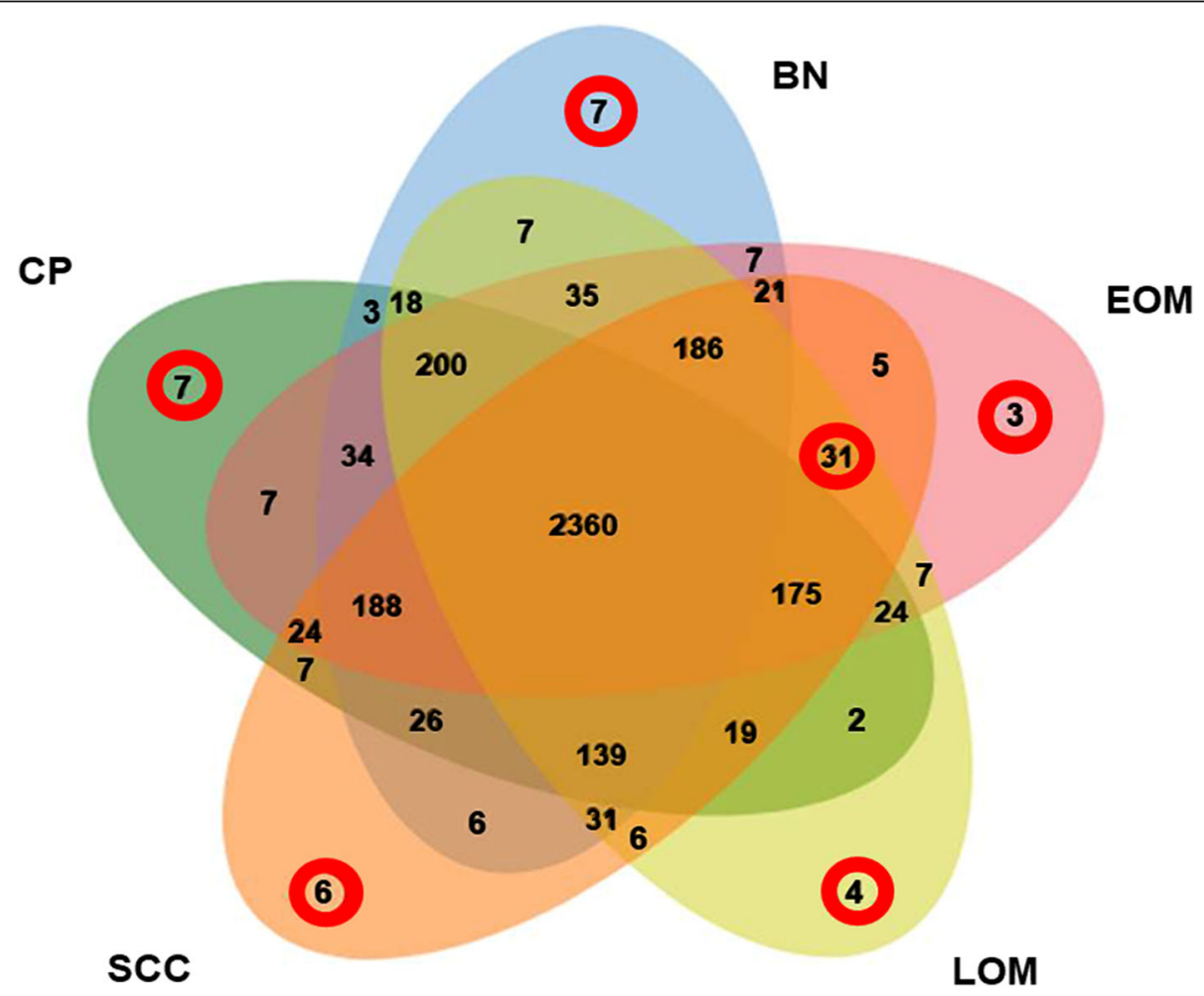

Fig. 1 Venn diagram of proteins differentially expressed in early-stage OM (EOM), late-stage OM (LOM), oral squamous cell carcinoma (OSCC), benign oral tumors (BN) and normal and periodontitis (CP). Circles indicate overexpressed proteins uniquely found in each group and commonly found in all cancerous groups 


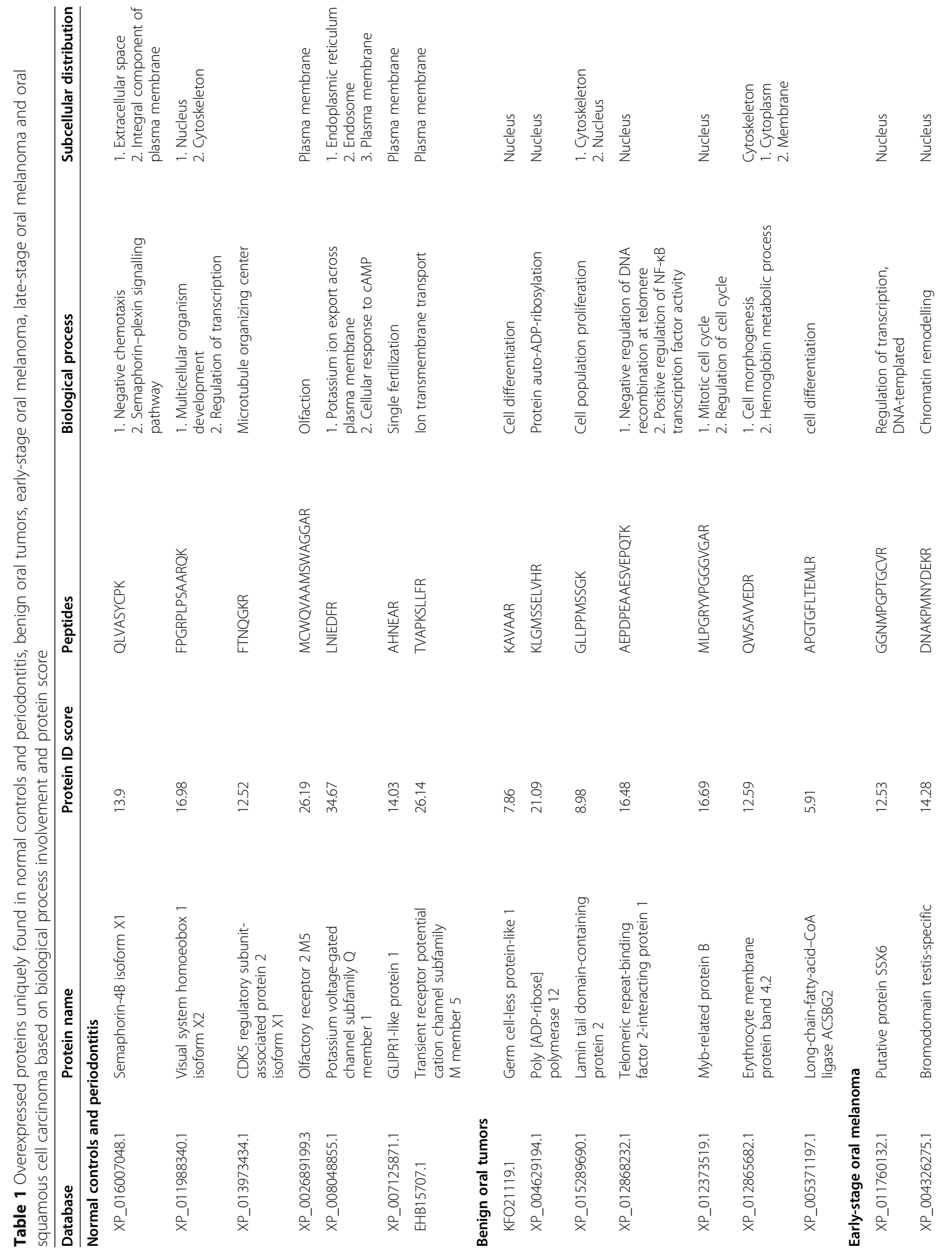




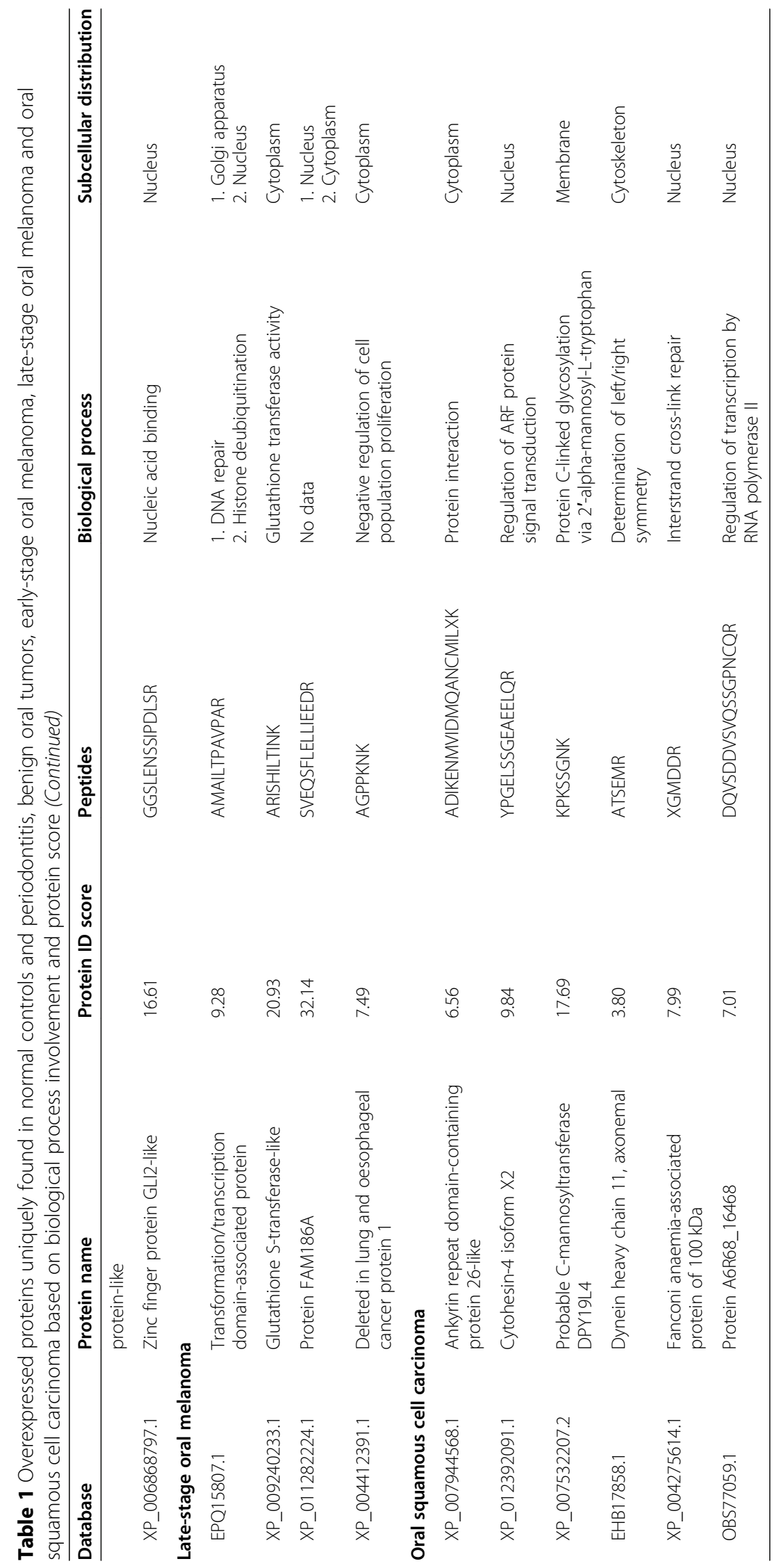




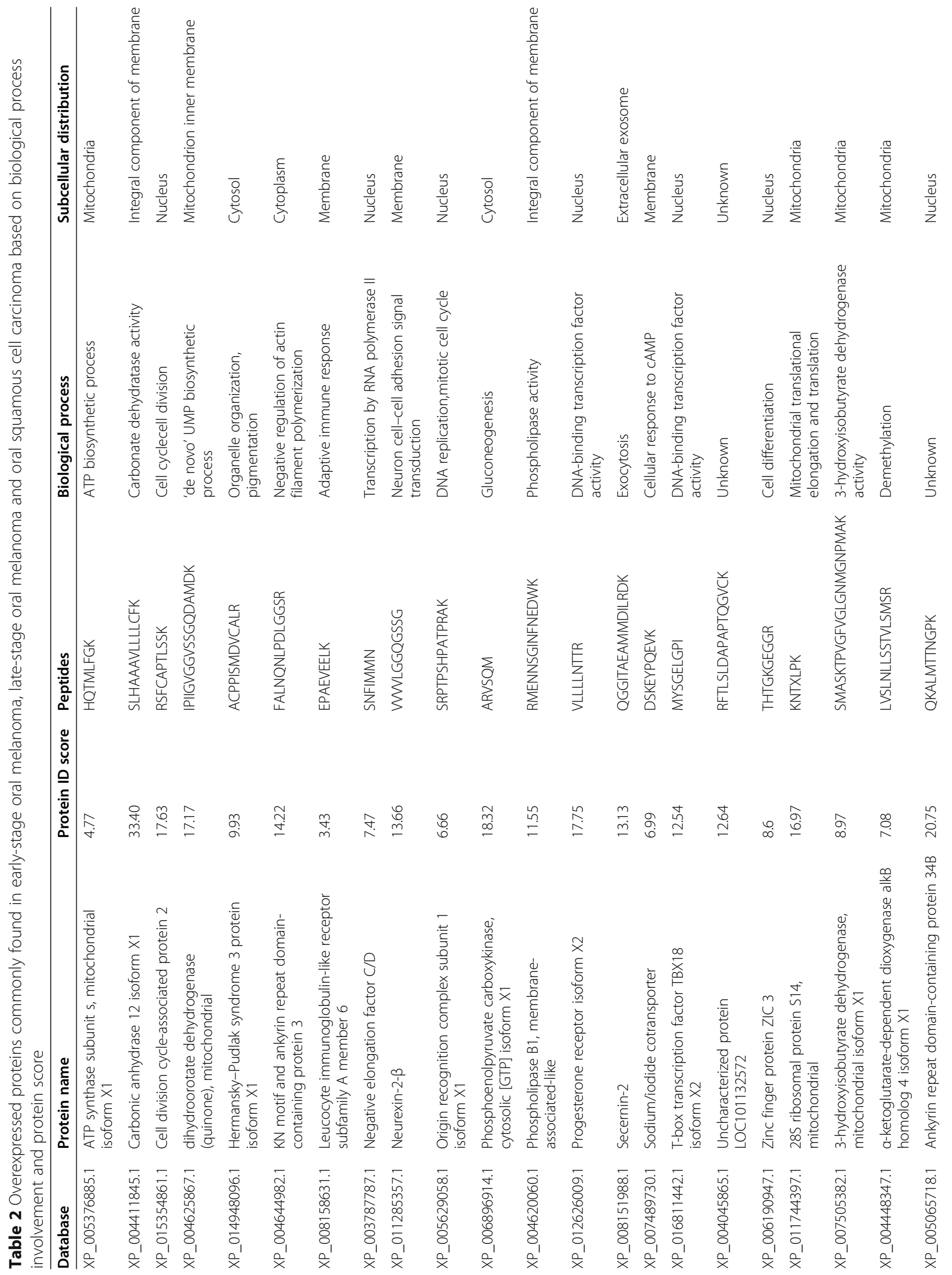




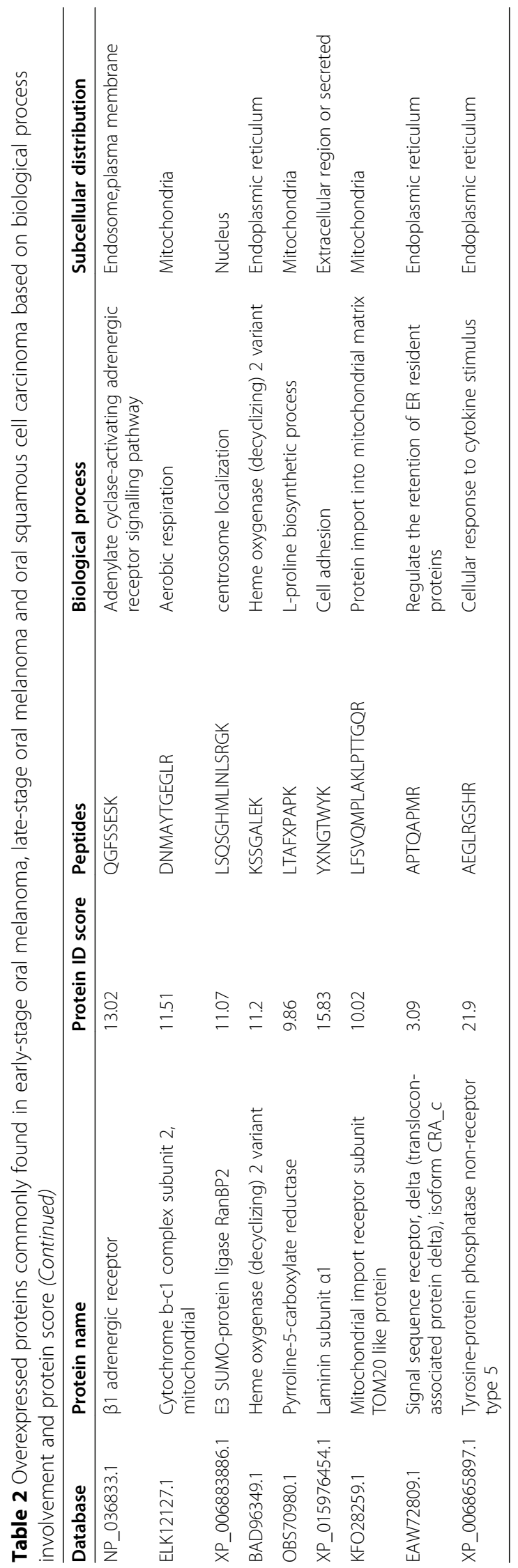


a

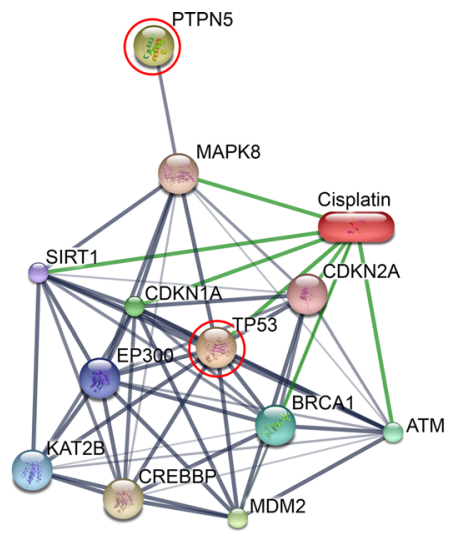

b

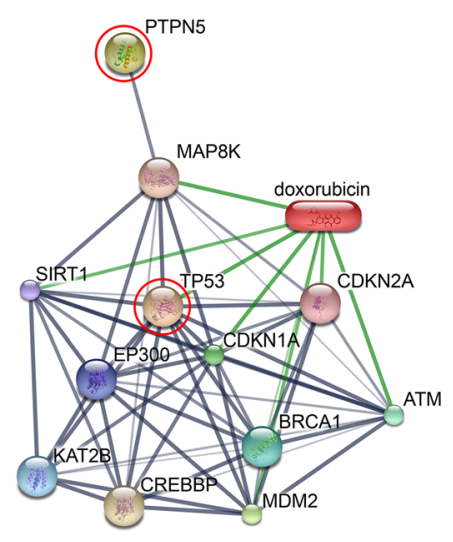

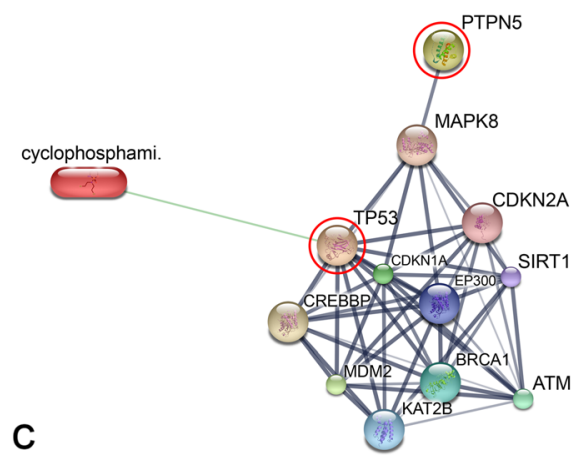

Fig. 2 Involvement of tyrosine-protein phosphatase non-receptor type 5 (PTPN5) and tumor protein p53 (TP53) in networks of protein chemotherapy drug interactions, cisplatin and doxorubicin, analysed by Stitch, version 5.0; a Interactions of PTPN5 and TP53 with cisplatin; $\mathbf{b}$ Interactions of PTPN5 and TP53 with doxorubicin; $\mathbf{c}$ Interactions of PTPN5 and TP53 with cyclophosphamide. Red circles: PTPN5 and TP53. Abbreviations: ataxia telangiectasia mutated (ATM), breast cancer 4721, early onset (BRCA1), cyclin-dependent kinase inhibitor 1A (p21, Cip1) (CDKN1A), cyclin-. 34,473 dependent kinase inhibitor 2A (CDKN2A), CREB binding protein (CREBBP), E1A binding 474 protein p300 (EP300), K (lysine) acetyltransferase 2B (KAT2B), mitogen-activated protein kinase 4758 (MAPK8), Mdm2 (MDM2) and sirtuin 1 (SIRT1).

with that in the CP group (Figs. 3 and 4). In addition, the expression of PTPN5 in LOM and OSCC was augmented compared with that in BN and EOM (Fig. 3). For tissue samples, we did not detect PTPN5 antibody binding to the tissue proteins (Data not shown). For the p53 western blotting, increased expression of p53 was observed in LOM compared with the control group (Fig. 5). Peptide sequences of PTPN5 and p53 western blot analysis were verified by LC-MS/MS (Fig. 6).

\section{Discussion}

In the present study, GeLC-MS/MS was used to identify novel salivary biomarker candidates in canine oral tumors. PTPN5 and p53 were plausibly shown to be candidates in LOM and OSCC. PTP is a group of protein tyrosine phosphatases that have divergent functions, either promoting or suppressing cancer. Several oncogenic PTPs have been reported to be highly expressed in human breast cancer [12]. In contrast to receptor-type PTPs that localized to the plasma membranes, the nonreceptor type PTPs, PTPNs, are located in the cytosol.
PTPN5 is in the same non-receptor Cys-based classical PTPs as PTPN1 and PTPN11, which promoted tumorigenesis in ovarian cancer, gastric cancer, prostate cancer, breast cancer, leukaemia, colorectal cancer and uveal melanoma [13-19]. PTPN1 has been reported to be increased in canine oral cancer tissues by MALDI-TOF MS plus LC-MS/MS [20]. PTPN1 functioned via Src/ Ras/Erk and PI3K/Akt pathways, whereas PTPN11 functioned via EGFR/Ras/MAPK pathways [15, 17, 21-23]. To the best of our knowledge, this study presented for the first time the association of salivary PTPN5 expression and canine oral cancers, particularly LOM and OSCC. Since most families of PTPs served as biomarker targets of several anticancer drugs, including PTPN11, PTPN6 and PTP1B, potential inhibitors of PTPN as candidate anticancer drugs for oral tumors should be investigated [24]. In the present study, we did not observe the expression of PTPN5 in any tissue proteins by western blotting. The plausible explanation included the expression of PTPN5 in saliva was not originated from the tumor tissues while proteins in saliva can be produced 
a

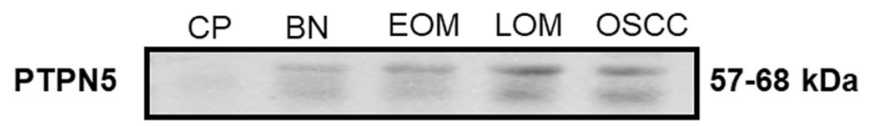

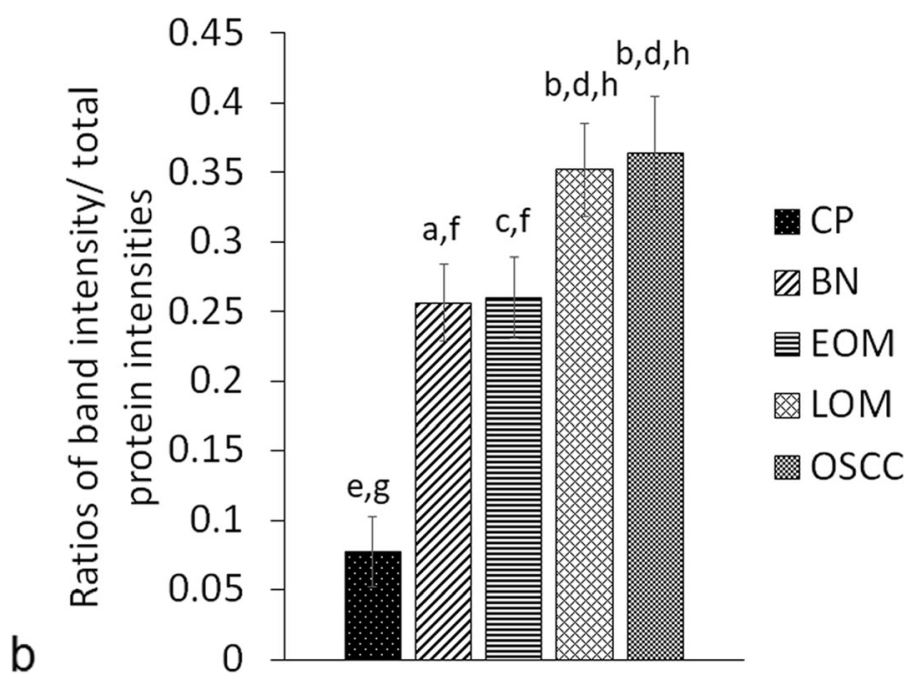

Fig. 3 Western blot analysis of salivary tyrosine-protein phosphatase non-receptor type 5 (PTPN5) of dogs with benign oral tumors (BN), early- and latestage oral melanoma (EOM and LOM, respectively), oral squamous cell carcinoma (OSCC) and periodontitis and normal controls (CP); a Representative western blot for PTPN5 at 57-68 kDa; $\mathbf{b}$ bar graph of ratios of PTPN5 protein intensity to total blotted proteins in each lane in a membrane; $a-b$ and c-d denote a significant difference at $P<0.05$; e-f denote a significant difference at $P<0.001$; g-h denote a significant difference at $P<0.0001$

from salivary glands or can also be transferred from systemic circulation [25].

In the present study, we also exhibited the enhanced expression of p53, in tumor groups, particularly in saliva of LOM and OSCC and in tissues of LOM group. Likewise, p53 was found in the interaction networks of PTPN5 and the chemotherapy drugs cisplatin and doxorubicin. p53 is a tumor suppressor protein; however, mutant p53 protein has been shown to be a biomarker in several cancers, such as human breast cancer, colorectal cancer, ovarian cancer, oesophageal squamous cell carcinoma, non-small cell lung cancer, and a prognostic marker in breast cancer, oesophageal squamous cell carcinoma, colon cancer, non-small cell lung cancer and B cell lymphoma [26-33]. In human head and neck squamous cell carcinoma, p53 mutation played an important role in tumorigenesis and progression. It has been used not only as a risk and prognostic biomarker, but also as a predictive biomarker in the clinical response to chemotherapy treatments [34-38]. Several studies, aiming to treat cancer in humans, have investigated the promoting function of wild-type p53 and degradation of mutant p53 $[29,39,40]$. Further investigation of p53 in canine oral tumors for potential prognostic and therapeutic biomarkers should be performed.

In the present study, increased expression of another protein involved in the SUMOylation process, RanBP2, was noted in a cancerous group (Table 2). In our previous study of salivary proteomics of canine oral tumors using MALDI-TOF MS and LC-MS/MS, the expression of sentrin-specific protease 7 (SENP7) was found to be increased in saliva of dogs with BN, EOM, LOM and OSCC. And according to the western blot analysis to validate MS results in individual samples, the enhanced expression of SENP7 has been observed in LOM and OSCC, compared with that in $\mathrm{CP}$ and $\mathrm{BN}$ [6]. SENP7 functions to edit the poly-small ubiquitin-related modifier (SUMO) chains during SUMOylation, a posttranslational modification of target proteins involving in several carcinogenic mechanisms [41]. In the present study using the same samples with the previous one, we found the expression of predicted SENP7 (Accession number: XP_008265236.1) in CP, BN, EOM and LOM groups but not in the OSCC group (Additional file 1). And this is probably due to different MS techniques and data analysis methods including different sample preparations, ionization approaches, and statistical analysis [20]. For MALDI-TOF MS coupled with LC-MS/MS, unique PMF peak spectra were previously selected by ClinProTools program before being sequenced by LCMS/MS. For GeLC-MS/MS, all proteins were loaded into the SDS-PAGE, trypsinized and applied to LC-MS/ MS. Proteins was quantitated using DeCyder MS Differential Analysis software, searched against the NCBI mammal database using MASCOT software and grouped by jvenn diagram. And that is the reason why 


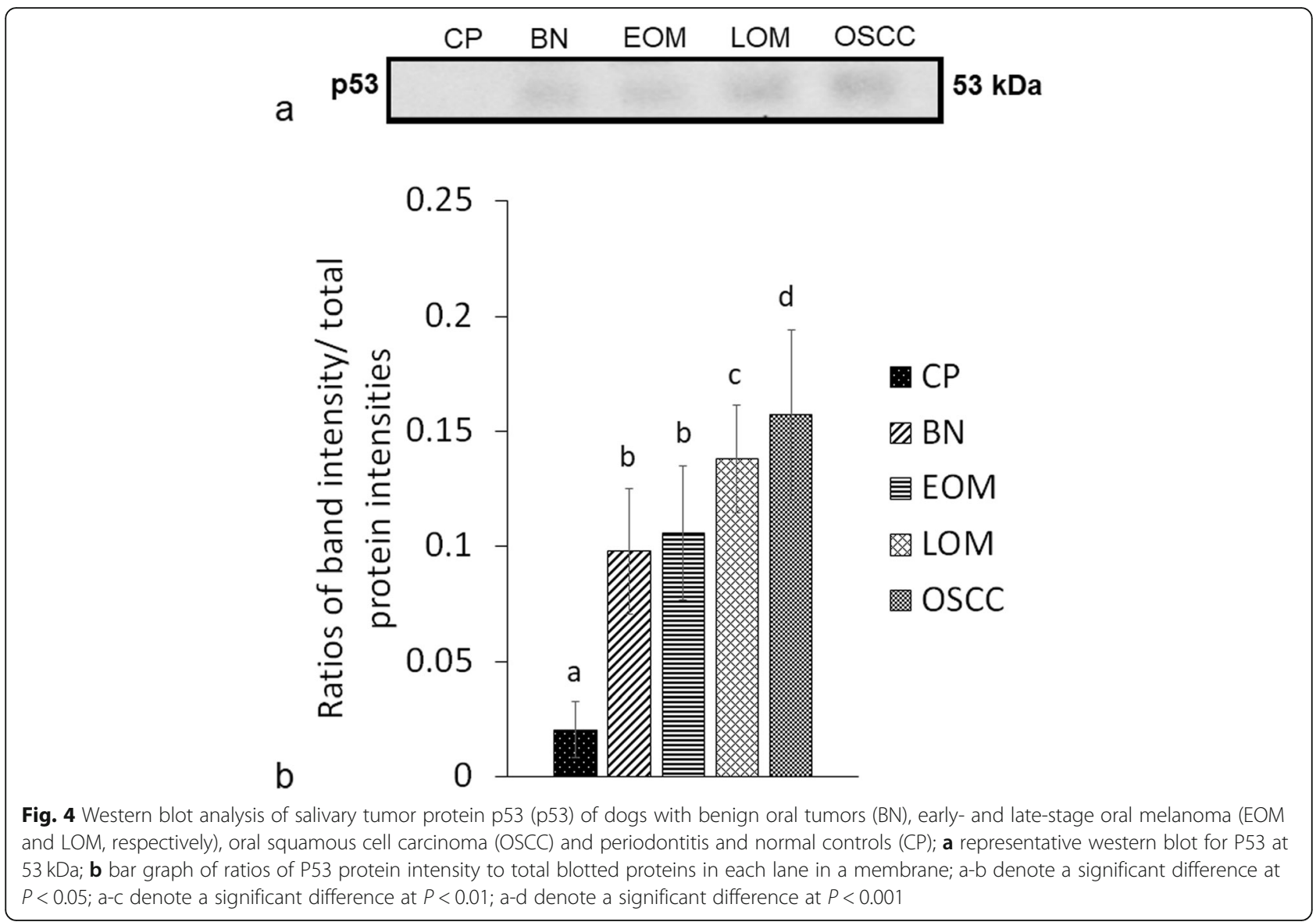

we require traditional protein detection methods such as western blots to confirm the proteomic results.

\section{Conclusion}

The present study used GeLC-MS/MS and western blotting to reveal the potential salivary biomarkers of canine oral tumors, PTPN5 and p53. The network interactions between the candidate proteins and chemotherapy drugs were also demonstrated. For future work, signalling pathways and potential inhibitors of the target proteins should be investigated as potential anticancer drugs for canine oral tumors.

\section{Methods}

\section{Animals}

Saliva samples were recruited from dogs with EOM $(n=$ $5)$, LOM $(n=24)$, OSCC $(n=10)$ and $\mathrm{BN}(n=11)$ (age range 7-14 years) whereas tissue samples were taken from 11 LOM, 9 OSCC and 9 BN dogs. Patient characteristics were shown in Tables 3 and 4 . Patients were scheduled for surgical operations at the Small Animal Teaching Hospital, Faculty of Veterinary Science, Chulalongkorn University and private animal hospitals. They were diagnosed with no prior history of treatments with chemotherapy and/or radiotherapy. The TNM staging of $\mathrm{OM}$ and OSCC were determined according to the WHO, whereby EOM and LOM include stages 1-2 and $3-4$, respectively [42, 43]. Regional lymph nodes were examined cytologically for metastasis. Tumor spreading to abdominal organs was checked by an ultrasound examination. Skull-to-abdomen radiography was performed by a Brivo DR-F digital X-ray system (GE Healthcare, Chicago, IL, USA) or an Optima CT660 64slice CT scanner (GE Healthcare). Seven saliva samples and 10 normal gingival tissue samples were obtained from healthy dogs with no history or clinical signs of oral cavity or cancers (age range 7-8 years). A chronic periodontitis group contained 5 dogs showing gingivitis, dental tartar and/or periodontal attachment loss (age range $7-13$ years). The sample collection protocol was approved by the Chulalongkorn University Animal Care and Use Committee (CU-ACUC), Thailand (Approval number 1631042) and written informed consents were obtained from all dog owners.

\section{Sample collection and preparation}

Saliva was collected on the day of surgery without stimulation. Dogs were fasted for at least $1 \mathrm{~h}$ and their mouths 


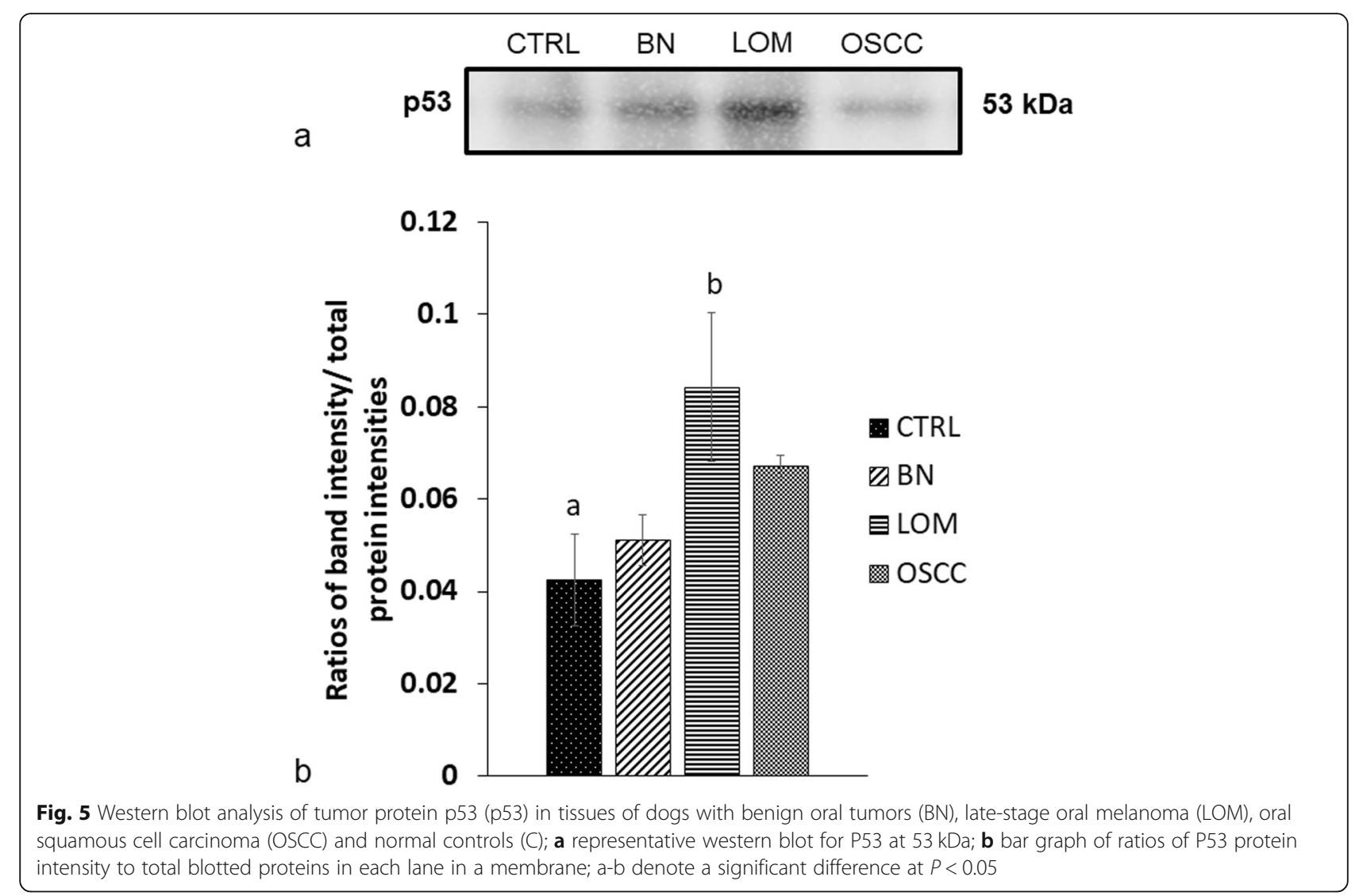

were rinsed with $0.9 \%$ sterile saline solution [9]. Whole saliva $(0.5-1.0 \mathrm{~mL})$ was collected for 5-10 min using a sterile cotton swab. After centrifugation at $2600 \times$ g for 15 min at $4{ }^{\circ} \mathrm{C}$ [44], Halt protease inhibitor cocktail (Thermo Fisher Scientific, Waltham, MA, USA) was added to $200 \mu \mathrm{L}$ of supernatant and samples were kept at $-20^{\circ} \mathrm{C}$ until analysis. Total protein concentrations were determined by the Lowry method, using bovine serum albumin as a protein standard [45]. According to our previous peptide profiles obtained from MALDI-TOF MS data, showing the control and chronic periodontitis in the same cluster, control and chronic periodontitis samples were consequently combined as a $\mathrm{CP}$ group [6]. For the tissues, samples were kept in RNALater solution at $-20^{\circ} \mathrm{C}$ until use.

\section{Analysis of salivary peptides by GeLC-MS/MS}

Salivary peptides were analysed by GeLC-MS/MS as previously described with some modifications [20]. Briefly, $50 \mu \mathrm{g}$ of pooled samples in each group (CP, BN, EOM, LOM and OSCC) were mixed with loading buffer [0.5 M dithiothreitol (DTT), 10\% w/v SDS, $0.4 \mathrm{M}$ Tris- $\mathrm{HCl} \mathrm{pH}$ $6.8,50 \% \mathrm{v} / \mathrm{v}$ glycerol, $0.1 \mathrm{mg} / \mathrm{ml}$ Bromophenol Blue] and boiled at $90^{\circ} \mathrm{C}$ for $5 \mathrm{~min}$ prior to separating on $12.5 \%$ SDS-PAGE (Atto, Tokyo, Japan). Gels were fixed using $50 \%$ methanol, acetic acid and 37\% formaldehyde and stained with silver nitrate solution, before being scanned using a GS-710 scanner (Bio-Rad Laboratories, Benicia, CA, USA) and stored in $0.1 \%$ acetic acid. After that ingel tryptic digestion was performed where protein bands in each lane were divided into 17 segments and chopped into $1 \mathrm{~mm}^{3}$ pieces. Gel pieces were dehydrated using $100 \%$ acetonitrile $(\mathrm{ACN})$ and dried. Cysteines were reduced and alkylated by $10 \mathrm{mM}$ DTT in $10 \mathrm{mM}$ ammonium bicarbonate and $100 \mathrm{mM}$ iodoacetamide in $10 \mathrm{mM}$ ammonium bicarbonate, respectively, prior to dehydrating twice in $100 \% \mathrm{ACN}$. After trypsin digestion in 50

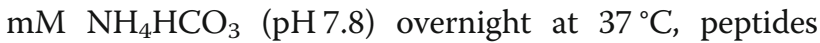
were extracted from the gels using $50 \% \mathrm{ACN}$ in $0.1 \%$ formic acid (FA). Pooled samples were submitted to a reversed-phase high performance liquid chromatography (HPLC). The gradient-eluted peptides were analysed using an Ultimate 3000 LC System coupled to an HCTUltra PTM Discovery System (Bruker Daltonics, Bremen, Germany). Peptides were separated on a PepSwift monolithic column $(100 \mu \mathrm{m}$ internal diameter $\times 50$ $\mathrm{mm})$ (Thermo Fisher Scientific). Peptide separation was achieved with a linear gradient at a flow rate of $1000 \mathrm{~nL} /$ min from $4 \% \mathrm{ACN}, 0.1 \% \mathrm{FA}$ to $70 \% \mathrm{ACN}, 0.1 \% \mathrm{FA}$ for 7.5 min with a regeneration step at $90 \% \mathrm{ACN}, 0.1 \% \mathrm{FA}$ and an equilibration step at $4 \% \mathrm{ACN}, 0.1 \% \mathrm{FA}$. The entire process took $20 \mathrm{~min}$. Peptide fragment mass spectra 


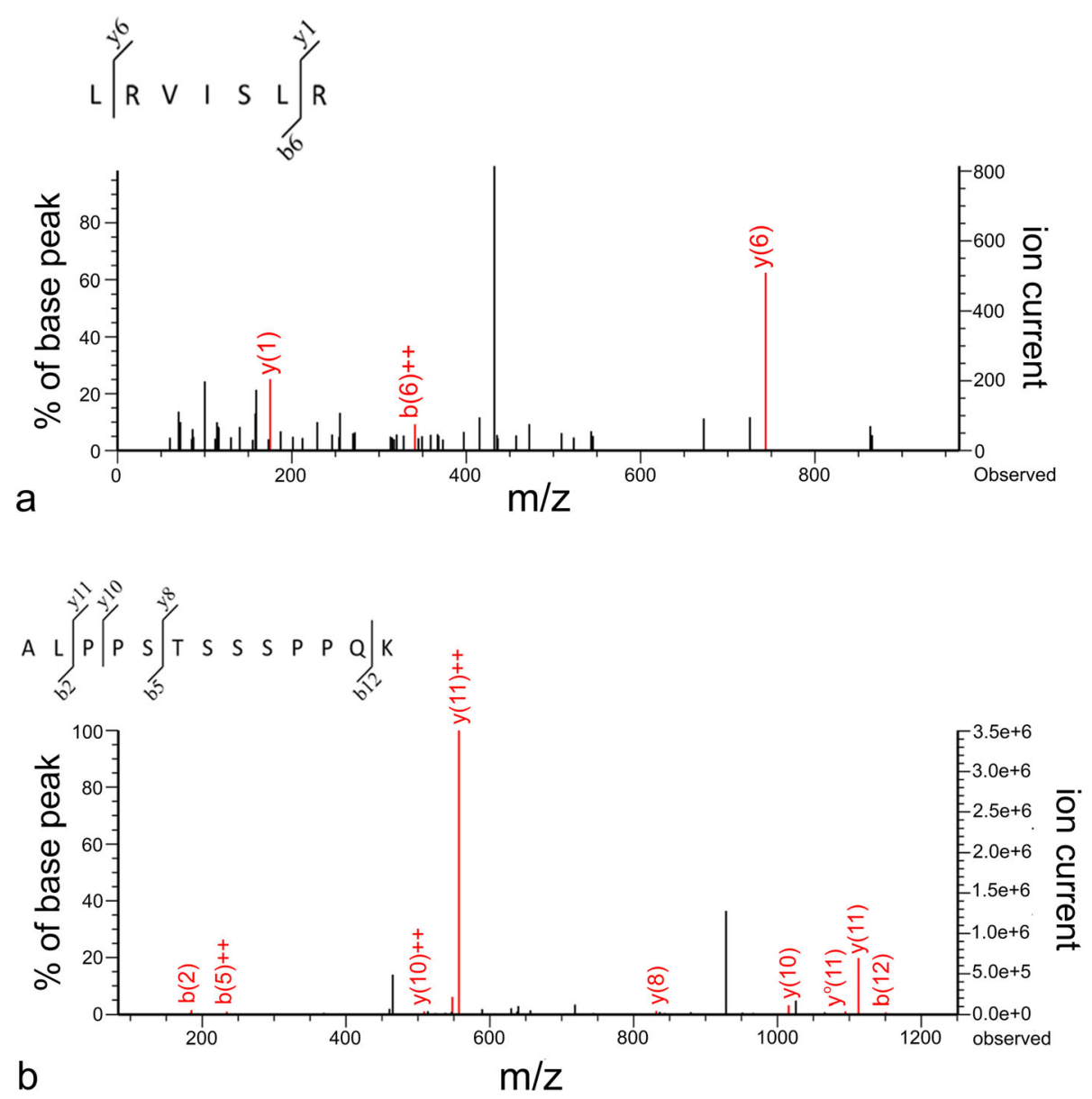

Fig. 6 Verification of expressed protein sequences by LC-MS/MS; a MS/MS fragmentations of LRVISLR found in salivary tyrosine-protein phosphatase non-receptor type 5 (PTPN5); b ALPPSTSSSPPQK found in salivary tumor protein p53 (p53)

were acquired in a data-dependent Auto MS mode with a scan range $400-1500 \mathrm{~m} / \mathrm{z}$. However, in the case of having more than 5 precursor fragments, peptides would be selected from the MS scan at 200-2800 m/z. CompassXport software (Bruker Daltonics) was used to convert data from LC-MS/MS into the mzXML format. Protein quantitation was performed using DeCyder MS Differential Analysis software (DeCyderMS, GE Healthcare) [46, 47]. The peptide sequences were searched against the NCBI mammal database for protein identification using MASCOT software, version 2.2 (Matrix Science, London, UK) [48]. Database query included taxonomy (mammals), enzyme (trypsin), variable modifications (oxidation of methionine residues), mass values (monoisotopic), protein mass (unrestricted), peptide mass tolerance $(1.2 \mathrm{Da})$, fragment mass tolerance $( \pm 0.6 \mathrm{Da})$, peptide charge state $(1+, 2+$ and $3+)$ and maximum number of missed cleavages. Proteins were identified from one or more peptides with an individual MASCOT score corresponding to $P<0.05$. Proteins were annotated by UniProtKB/Swiss-Prot entries (http://www.uniprot. org/) and classified according to their molecular function, biological process and cellular component using the PANTHER classification system, version 8.1 (www. pantherdb.org/) [49]. Protein list comparison among different sample groups was displayed using jvenn diagram (http://bioinfo.genotoul.fr/jvenn/example.html) [50]. The interaction network of candidate proteins and chemotherapy drugs was explored using the Stitch program, version 5.0 (http://stitch.embl.de/) [51].

\section{Validation of MS results by western blot analysis}

Protein concentrations of pooled saliva and tissue samples were determined by Lowry assay, SDS-PAGE and western blotting as described previously $[6,52]$. Briefly, samples $(10 \mu \mathrm{g})$ were mixed with loading dye, heated and applied to a pre-cast NuPAGE $4-12 \%(\mathrm{w} / \mathrm{v})$ BisTris gel (Thermo Fisher Scientific) using RunBlue MES Run Buffer (Expedeon, Heidelberg, Germany) at $200 \mathrm{~V}$ for $90 \mathrm{~min}$. Protein standard marker was 
Table 3 Patient characteristics of the saliva of canine samples

\begin{tabular}{|c|c|c|c|c|c|}
\hline Sample no. & Groups $^{a}$ & Histological examination & Age (y) & Sex $^{b}$ & Breed \\
\hline 1 & Control & Normal gingiva & 8 & $\mathrm{~F}$ & Beagle \\
\hline 2 & Control & Normal gingiva & 8 & $\mathrm{~F}$ & Beagle \\
\hline 3 & Control & Normal gingiva & 8 & $\mathrm{~F}$ & Beagle \\
\hline 4 & Control & Normal gingiva & 8 & $\mathrm{~F}$ & Beagle \\
\hline 5 & Control & Normal gingiva & 8 & $\mathrm{~F}$ & Beagle \\
\hline 6 & Control & Normal gingiva & 8 & $\mathrm{~F}$ & Beagle \\
\hline 7 & Control & Normal gingiva & 8 & $\mathrm{~F}$ & Beagle \\
\hline 8 & Periodontitis & Gingival hyperplasia & 10 & Mc & Mixed \\
\hline 9 & Periodontitis & Gingival hyperplasia & 12 & Fs & Golden Retriever \\
\hline 10 & Periodontitis & Gingival hyperplasia & 10 & M & Mixed \\
\hline 11 & Periodontitis & Gingival hyperplasia & 9 & M & Pomeranian \\
\hline 12 & Periodontitis & Gingival hyperplasia & 14 & Fs & Shi-tsu \\
\hline 13 & Benigh oral tumor & Peripheral odontogenic fibroma & 7 & Fs & Poodle \\
\hline 14 & Benigh oral tumor & Acanthomatous ameloblastoma & 10 & $\mathrm{~F}$ & Shi-tsu \\
\hline 15 & Benigh oral tumor & Acanthomatous ameloblastoma & 11 & $\mathrm{~F}$ & Labrador retriever \\
\hline 16 & Benigh oral tumor & Peripheral odontogenic fibroma & 10 & Mc & Mixed \\
\hline 17 & Benigh oral tumor & Peripheral odontogenic fibroma & 10 & M & Poodle \\
\hline 18 & Benigh oral tumor & Peripheral odontogenic fibroma & 8 & Mc & Siberian husky \\
\hline 19 & Benigh oral tumor & Peripheral odontogenic fibroma & 10 & Fs & Siberian husky \\
\hline 20 & Benigh oral tumor & Peripheral odontogenic fibroma & $9 Y$ & M & Shi-Tzu \\
\hline 21 & Benigh oral tumor & Peripheral odontogenic fibroma & $14 Y$ & M & Golden Retriever \\
\hline 22 & Benigh oral tumor & Peripheral odontogenic fibroma & $2 Y$ & $\mathrm{~F}$ & Golden Retriever \\
\hline 23 & Benigh oral tumor & Acanthomatous ameloblastoma & 11 & Fs & Golden Retriever \\
\hline 24 & oscC & well differentiated & 11 & M & Mixed \\
\hline 25 & oscC & well differentiated & 13 & Fs & Cocker spaniel \\
\hline 26 & oscC & poorly differentiated & 9 & M & Shi-tsu \\
\hline 27 & OSCC & well differentiated & 14 & Fs & Pug \\
\hline 28 & oscC & poorly differentiated & 15 & Mc & Poodle \\
\hline 29 & oscC & well differentiated & 11 & Fs & Poodle \\
\hline 30 & OSCC & well differentiated & 11 & M & Mixed \\
\hline 31 & oscC & poorly differentiated & 12 & $\mathrm{~F}$ & Bangkeaw \\
\hline 32 & oscC & well differentiated & 12 & $\mathrm{~F}$ & Mixed \\
\hline 33 & oscC & poorly differentiated & 11 & M & Mixed \\
\hline 34 & Early-stage OM (I) & Melanotic melanoma & 10 & M & Poodle \\
\hline 35 & Early-stage OM (I) & Amelanotic melanoma & 14 & M & Mixed \\
\hline 36 & Early-stage OM (II) & Melanotic melanoma & 10 & Fs & Mixed \\
\hline 37 & Early-stage OM (II) & Melanotic melanoma & 11 & M & chihuahua \\
\hline 38 & Early-stage OM (II) & Amelanotic melanoma & 12 & M & Poodle \\
\hline 39 & Late-stage OM (III) & Melanotic melanoma & 12 & M & Pug \\
\hline 40 & Late-stage OM (III) & Melanotic melanoma & 12 & M & Labrador retriever \\
\hline 41 & Late-stage OM (IV) & Melanotic melanoma & 14 & M & Cocker spaniel \\
\hline 42 & Late-stage OM (III) & Melanotic melanoma & 8 & M & Schnauzer \\
\hline 43 & Late-stage OM & Amelanotic melanoma & 11 & M & Poodle \\
\hline
\end{tabular}


Table 3 Patient characteristics of the saliva of canine samples (Continued)

\begin{tabular}{|c|c|c|c|c|c|}
\hline Sample no. & Groups $^{a}$ & Histological examination & Age (y) & Sex $^{b}$ & Breed \\
\hline$\overline{44}$ & $\begin{array}{l}\text { Late-stage OM } \\
\text { (III) }\end{array}$ & Melanotic melanoma & 15 & $M$ & Shi-tsu \\
\hline 45 & Late-stage OM (III) & Melanotic melanoma & 13 & Fs & Golden Retriever \\
\hline 46 & Late-stage OM (III) & Melanotic melanoma & 14 & M & Mixed \\
\hline 47 & Late-stage OM (III) & Melanotic melanoma & 13 & $\mathrm{~F}$ & Poodle \\
\hline 48 & Late-stage OM (III) & Melanotic melanoma & 12 & M & Pomeranian \\
\hline 49 & Late-stage OM (IV) & Melanotic melanoma & 15 & M & Golden Retriever \\
\hline 50 & Late-stage OM (III) & Amelanotic melanoma & 13 & M & Cocker spaniel \\
\hline 51 & Late-stage OM (III) & Melanotic melanoma & 14 & M & Golden Retriever \\
\hline 52 & Late-stage OM (III) & Melanotic melanoma & 12 & M & Mixed \\
\hline 53 & Late-stage OM (III) & Amelanotic melanoma & 10 & M & Mixed \\
\hline 54 & Late-stage OM (III) & Melanotic melanoma & 14 & M & Mixed \\
\hline 55 & Late-stage OM (III) & Melanotic melanoma & 15 & M & Poodle \\
\hline 56 & Late-stage OM (III) & Melanotic melanoma & 8 & M & Golden Retriever \\
\hline 57 & Late-stage OM (III) & Melanotic melanoma & 10 & Fs & Beagle \\
\hline 58 & Late-stage OM (III) & Amelanotic melanoma & 10 & M & Mixed \\
\hline 59 & Late-stage OM (III) & Amelanotic melanoma & 8 & M & Mixed \\
\hline 60 & Late-stage OM (III) & Amelanotic melanoma & 12 & Fs & Dachshund \\
\hline 61 & Late-stage OM (IV) & Melanotic melanoma & 14 & M & Poodle \\
\hline 62 & Late-stage OM (III) & Melanotic melanoma & 12 & $\mathrm{~F}$ & Golden Retriever \\
\hline
\end{tabular}

Clinical stages are in parentheses

${ }^{a} O M$ Oral melanoma, OSCC Oral squamous cell carcinoma

${ }^{\mathrm{b}} M$ Male, Mc Male castration, F Female, Fs Female spray

PageRuler prestained protein ladder (molecular weight range $10-180 \mathrm{kDa}$ ) (Thermo Fisher Scientific). After that, the proteins were transferred to TranBlot Turbo nitrocellulose membranes (Bio-Rad Laboratories) at $25 \mathrm{~V}$ for $14 \mathrm{~min}$ using Trans-Blot Turbo $5 \times$ transfer buffer (Bio-Rad Laboratories). Detection of total protein band intensities in each lane was performed by a Pierce Reversible Protein Stain Kit for Nitrocellulose Membranes (Thermo Fisher Scientific) according to the manufacturer's instructions. Blocking non-specific protein binding was achieved by $5 \%$ bovine serum albumin (BSA) (GoldBio, St Louis, MO, USA) in Trisbuffered saline containing $0.1 \%$ Tween 20 (TBST) at $25^{\circ} \mathrm{C}$ overnight. After washing with TBST, primary antibodies diluted at 1:1000 were incubated with a membrane at $4{ }^{\circ} \mathrm{C}$ overnight, including mouse monoclonal anti-human PTPN5 or STEP (F-9) (Cat. No. sc-514,678, Santa Cruz Biotechnology, Dallas, TX, USA) and mouse monoclonal anti-human p53 (DO-1) (Cat. No. sc-126, Santa Cruz Biotechnology, Dallas, TX, USA). Membranes were washed with TBST and then incubated with 1:10000 horseradish peroxidase conjugated-rabbit anti-mouse IgG secondary antibody (Abcam, Cambridge, UK) for $1 \mathrm{~h}$ at $25^{\circ} \mathrm{C}$. The proteins of interest were visualized with $\mathrm{ECL}$ western blotting detection reagents (GE Healthcare). Western blot imaging was performed using a ChemiDoc Touch Imaging System (Bio-Rad Laboratories). Protein bands intensities were analysed by Image Lab 6.0.1 software (Bio-Rad Laboratories). Total protein normalization was performed with the modification of Aldridge et al. (2008) [6, 53]. The ratios of target band intensities to the total proteins in each lane were calculated as previously described [6]. The western blotting was performed in triplicate.

\section{Verification of expressed protein sequences by LC-MS/MS} LC-MS/MS was utilized to confirm PTPN5 and p53 (or TP53) protein identities as described previously [6]. Briefly, blotting membranes were incubated with Restore Plus Western Blot Stripping Buffer (Thermo Fisher Scientific) for $15 \mathrm{~min}$ and washed 4 times with TBST. Protein bands were excised and stored in $10 \mathrm{mM}$ DTT in $10 \mathrm{mM}$ ammonium bicarbonate overnight. Samples were then trypsinized at $37^{\circ} \mathrm{C}$ for $3 \mathrm{~h}$ and applied to the $\mathrm{LC}$ MS/MS as mentioned above.

\section{Statistical analysis}

ANOVA statistical analysis, incorporated into the DeCyder MS differential analysis software, and MASCOT 
Table 4 Patient characteristics of the canine gingival tissues

\begin{tabular}{|c|c|c|c|c|c|}
\hline Sample no. & Groups $^{\text {b }}$ & Histological examination & Age (year) & $\operatorname{Sex}^{\mathbf{b}}$ & Breed \\
\hline 1 & Control & Normal gingiva & 8 & $\mathrm{~F}$ & mixed \\
\hline 2 & Control & Normal gingiva & 6 & M & mixed \\
\hline 3 & Control & Normal gingiva & 7 & M & mixed \\
\hline 4 & Control & Normal gingiva & 4 & Mc & Beagle \\
\hline 5 & Control & Normal gingiva & 1 & $\mathrm{~F}$ & mixed \\
\hline 6 & Control & Normal gingiva & 8 & $\mathrm{~F}$ & Beagle \\
\hline 7 & Control & Normal gingiva & 8 & $\mathrm{~F}$ & Beagle \\
\hline 8 & Control & Normal gingiva & 8 & $\mathrm{~F}$ & Beagle \\
\hline 9 & Control & Normal gingiva & 8 & $\mathrm{~F}$ & Beagle \\
\hline 10 & Control & Normal gingiva & 8 & $\mathrm{~F}$ & Beagle \\
\hline 11 & benign oral tumor & Acanthomatous ameloblastoma & 8 & Fs & Rottweiler \\
\hline 12 & benign oral tumor & Acanthomatous ameloblastoma & 9 & Mc & mixed \\
\hline 13 & benign oral tumor & Peripheral odontogenic fibroma & 6 & Mc & Shi-Tzu \\
\hline 14 & benign oral tumor & Acanthomatous ameloblastoma & 7 & $\mathrm{~F}$ & Beagle \\
\hline 15 & benign oral tumor & Acanthomatous ameloblastoma & 8 & Fs & Chi hua hua \\
\hline 16 & benign oral tumor & Peripheral odontogenic fibroma & 9 & M & Shi-Tzu \\
\hline 17 & benign oral tumor & Peripheral odontogenic fibroma & 14 & M & Golden Retriever \\
\hline 18 & benign oral tumor & Peripheral odontogenic fibroma & 2 & $\mathrm{~F}$ & Golden Retriever \\
\hline 19 & benign oral tumor & Acanthomatous ameloblastoma & 6 & M & Mixed \\
\hline 20 & OSCC & poorly differentiated & 10 & $\mathrm{~F}$ & Mixed \\
\hline 21 & OSCC & well differentiated & 17 & Fs & Shi-Tzu \\
\hline 22 & OSCC & poorly differentiated & 10 & M & Mixed \\
\hline 23 & oscC & well differentiated & 3 & M & Shi-Tzu \\
\hline 24 & oscC & well differentiated & 11 & M & Schnauzer \\
\hline 25 & oscC & well differentiated & 10 & M & mixed \\
\hline 26 & OSCC & well differentiated & 15 & Fs & Miniature pinscher \\
\hline 27 & oscC & well differentiated & 10 & Mc & mixed \\
\hline 28 & oscC & well differentiated & 10 & M & Shi-Tzu \\
\hline 29 & $\begin{array}{l}\text { Late-stage OM } \\
\text { (IV) }\end{array}$ & Amelanotic melanoma & 12 & Fs & Mixed \\
\hline 30 & $\begin{array}{l}\text { Late-stage OM } \\
\text { (IV) }\end{array}$ & Melanotic melanoma & 13 & $\mathrm{~F}$ & English cocker spanie \\
\hline 31 & $\begin{array}{l}\text { Late-stage OM } \\
\text { (III) }\end{array}$ & Melanotic melanoma & 10 & Fs & Mixed \\
\hline 32 & $\begin{array}{l}\text { Late-stage OM } \\
\text { (III) }\end{array}$ & Amelanotic melanoma & 10 & M & Labrador Retriever \\
\hline 33 & $\begin{array}{l}\text { Late-stage OM } \\
\text { (III) }\end{array}$ & Melanotic melanoma & 14 & M & Golden Retriever \\
\hline 34 & $\begin{array}{l}\text { Late-stage OM } \\
\text { (III) }\end{array}$ & Amelanotic melanoma & 11 & M & Mixed \\
\hline 35 & $\begin{array}{l}\text { Late-stage OM } \\
\text { (III) }\end{array}$ & Melanotic melanoma & 10 & Fs & Poodle \\
\hline 36 & $\begin{array}{l}\text { Late-stage OM } \\
\text { (III) }\end{array}$ & Melanotic melanoma & 9 & Fs & Rottweiler \\
\hline 37 & $\begin{array}{l}\text { Late-stage OM } \\
\text { (III) }\end{array}$ & Melanotic melanoma & 12 & M & Mixed \\
\hline 38 & $\begin{array}{l}\text { Late-stage OM } \\
\text { (III) }\end{array}$ & Amelanotic melanoma & 10 & $\mathrm{~F}$ & Shi-Tzu \\
\hline
\end{tabular}


Table 4 Patient characteristics of the canine gingival tissues (Continued)

\begin{tabular}{llllll}
\hline Sample no. & Groups $^{\mathbf{b}}$ & Histological examination & Age (year) & Sex $^{\mathbf{b}}$ & Breed \\
\hline 39 & $\begin{array}{l}\text { Late-stage OM } \\
\text { (III) }\end{array}$ & Melanotic melanoma & 12 & Mc & German Shepherd \\
\hline
\end{tabular}

Clinical stages are in parentheses

${ }^{a}$ OM Oral melanoma, OSCC Oral squamous cell carcinoma

${ }^{\mathrm{b}} M$ Male, Mc Male castration, $F$ Female, Fs Female spray

software, version 2.2 were used to analyse significantly different peptide peak intensities and MASCOT LC-MS/ MS scores, respectively. Western blot analysis was performed by ordinary one-way ANOVA with Tukey's multiple comparisons for PTPN5 and p53. Statistical analyses of protein expression data were conducted using GraphPad Prism, version 8.0.1 (GraphPad Software, La Jolla, CA, USA). Significance was accepted at the $P<0.05$ level.

\section{Supplementary information}

Supplementary information accompanies this paper at https://doi.org/10. 1186/s12917-020-02550-w.

Additional file 1. The relative expression levels of proteins found in normal controls and periodontitis (CP), benign tumors $(B N)$, early-stage oral melanoma (EOM), late-stage oral melanoma (LOM) and oral squamous cell carcinoma (OSCC) as $\log _{2}$ intensities.

\section{Abbreviations}

ACN: Acetonitrile; Akt: Protein Kinase B; BN: Benign oral tumors; BSA: Bovine serum albumin; CU-ACUC: The Chulalongkorn University Animal Care and Use Committee; CP: Periodontitis and healthy controls; CT: Computer tomography; CPC: Chromosomal passenger complex; DTT: Dithiothreitol; EGFR: Epidermal growth factor receptor; EOM: Early-stage oral melanoma; Erk: Extracellular-signal-regulated-kinase; FA: Formic acid; GeLC-MS/MS: In-gel digestion coupled with mass spectrometry; HCTUltra: High-capacity ion trap mass spectrometry; HPLC: High performance liquid chromatography; i.d.: Inside diameter; IAA: Iodoacetamide; IgG: Immunoglobulin G; LC: Liquid chromatography; LOM: Late-stage oral melanoma; MALDI-TOF MS: Matrixassisted laser desorption ionization mass spectrometry; MAPK: Mitogenactivated protein kinase; MES buffer: 2-(N-morpholino) ethanesulfonic acid buffer; MS: Mass spectrometry; m/z: Mass per charge ratio; NCBI: National Center for Biotechnology Information; $\mathrm{NH}_{4} \mathrm{HCO}_{3}$ : Ammonium bicarbonate; OSCC: Oral squamous cell carcinoma; p53: Tumor protein p53; PI3K: Phosphoinositide-3 kinase; PTM: Post-Translation Modification; PTPN1: Protein tyrosine phosphatase non-receptor type 1; PTPN5: Protein tyrosine phosphatase non-receptor type 5; PTPN6: Protein tyrosine phosphatase non-receptor type 6; PTPN11: Protein tyrosine phosphatase non-receptor type 11; PTP1B: Protein tyrosine phosphatase 1B; RanB2: E3 SUMO-protein ligase RanBP2; Ras: Ras protein; SDS: Sodium dodecyl sulfate; SDS-PAGE: Sodium dodecyl sulfate-polyacrylamide gel electrophoresis; SENP3: SUMO Specific-isopeptidase; SENP7: Sentrin-specific protease 7; Src: Proto-oncogene tyrosine-protein kinase; SUMO: Small ubiquitin-like modifier; TBST: Tris buffered saline buffer containing 0.1\% Tween 20; TNM Stage: stages according to their primary sizes and metastatic profile, the tumor, node and metastasis; Topoll: Targeting DNA topoisomerase II; TrisHCl: Tris hydrochloride; WHO: World Health Organization

\section{Acknowledgements}

We sincerely thank Dr. Worapan Tadadoltip for sample collection. Special thanks to Ms. Janthima Jaresitthikunchai and Mr. Sucheewin Krobthong for technical assistance.

\section{Authors' contributions}

GS and SR designed the study. SP1, SP2, CK and AR collected samples. SP1, NP, SK and KL performed the experiments and analyses. GS and SP1 drafted the manuscript. GS and SR finalized the manuscript. All authors read and approved the final manuscript.

\section{Funding}

This work was supported by the TRF Research Career Development Grant (RSA grant) (grant number RSA5980053) (to G.S.); the 100th Anniversary of Chulalongkorn University for a Doctoral Scholarship (to S.P.); the 90th Anniversary of Chulalongkorn University Scholarship (to S.P.); and an Overseas Research Experience Scholarship for Graduate Student (to S.P.). The funders had no role in the design of the study and collection, analysis, and interpretation of data, or in writing the manuscript.

\section{Availability of data and materials}

The datasets used and/or analysed during the current study are available from the corresponding author on reasonable request.

\section{Ethics approval}

All experimental protocols were approved by the Chulalongkorn University Animal Care and Use Committee (CU-ACUC), Faculty of Veterinary Science, Chulalongkorn University (Approval number 1631042). All procedures were performed in accordance with the relevant guidelines and regulations. Written informed consents were obtained from all dog owners.

\section{Consent for publication}

Not applicable.

\section{Competing interests}

The corresponding author, Dr. Gunnaporn Suriyaphol, is an Associate Editor of this journal. Other authors declare that they have no competing interests.

\section{Author details}

'Biochemistry Unit, Department of Physiology, Faculty of Veterinary Science, Chulalongkorn University, 39 Henri-Dunant Road, Wangmai, Pathumwan, Bangkok 10330, Thailand. ${ }^{2}$ Companion Animal Cancer Research Unit, Faculty of Veterinary Science, Chulalongkorn University, 39 Henri-Dunant Road, Wangmai, Pathumwan, Bangkok 10330, Thailand. ${ }^{3}$ Proteomics Research Laboratory, National Center for Genetic Engineering and Biotechnology, National Science and Technology Development Agency, 113 Thailand Science Park, Phahonyothin Road, Khlong Nueng, Khlong Luang, Pathum Thani 12120, Thailand. ${ }^{4}$ Department of Surgery, Faculty of Veterinary Science, Chulalongkorn University, 39 Henri-Dunant Road, Wangmai, Pathumwan, Bangkok 10330, Thailand. ${ }^{5}$ Department of Pathology, Faculty of Veterinary Science, Chulalongkorn University, 39 Henri-Dunant Road, Wangmai, Pathumwan, Bangkok 10330, Thailand.

Received: 5 September 2019 Accepted: 31 August 2020

Published online: 14 September 2020

\section{References}

1. Bronden LB, Eriksen T, Kristensen AT. Oral malignant melanomas and other head and neck neoplasms in Danish dogs--data from the Danish veterinary Cancer registry. Acta Vet Scand. 2009;51:54.

2. Prein J, Remagen W, Spiessl B, Uehlinger E. Atlas of tumors of the facial skeleton: Odontogenic and nonodontogenic tumors: Springer Science \& Business Media; 2012. p. 1-3.

3. Liptak J, Withrow S. Cancer of the Gastrointestinal Tract. In: Withrow SJ, Vail DM, Page RL, editors. Withrow and MacEwen's Small Animal Clinical Oncology. 5th ed. St. Louis: Elsevier Saunders; 2013. p. 381-97.

4. Tuohy JL, Selmic LE, Worley DR, Ehrhart NP, Withrow SJ. Outcome following curative-intent surgery for oral melanoma in dogs: 70 cases (1998-2011). J Am Vet Med Assoc. 2014;245:1266-73. 
5. Nishiya AT, Massoco CO, Felizzola CR, Perlmann E, Batschinski K, Tedardi MV, et al. Comparative aspects of canine melanoma. Vet Sci. 2016;3:1-22.

6. Ploypetch S, Roytrakul S, Jaresitthikunchai J, Phaonakrop N, Krobthong S, Suriyaphol G. Salivary proteomics of canine oral tumors using MALDI-TOF mass spectrometry and LC-tandem mass spectrometry. PLoS One. 2019;14: e0219390.

7. Hu S, Arellano M, Boontheung P, Wang J, Zhou H, Jiang J, et al. Salivary proteomics for oral cancer biomarker discovery. Clin Cancer Res. 2008;14 6246-52.

8. Wu CC, Chu HW, Hsu CW, Chang KP, Liu HP. Saliva proteome profiling reveals potential salivary biomarkers for detection of oral cavity squamous cell carcinoma. Proteomics. 2015;15:3394-404.

9. Jou YJ, Lin CD, Lai CH, Chen CH, Kao JY, Chen SY, et al. Proteomic identification of salivary transferrin as a biomarker for early detection of oral cancer. Anal Chim Acta. 2010;681:41-8.

10. Chaiyarit P, Taweechaisupapong S, Jaresitthikunchai J, Phaonakrop N, Roytrakul S. Comparative evaluation of 5-15-kDa salivary proteins from patients with different oral diseases by MALDI-TOF/TOF mass spectrometry. Clin Oral Investig. 2015:19:729-37.

11. Ashikari D, Takayama K, Tanaka T, Suzuki Y, Obinata D, Fujimura T, et al. Androgen induces G3BP2 and SUMO-mediated p53 nuclear export in prostate cancer. Oncogene. 2017;36:6272-81.

12. den Hollander P, Rawls K, Tsimelzon A, Shepherd J, Mazumdar A, Hill J, et al. Phosphatase PTP4A3 promotes triple-negative breast cancer growth and predicts poor patient survival. Cancer Res. 2016;76:1942-53.

13. Xu R, Yu Y, Zheng S, Zhao X, Dong Q, He Z, Liang Y, Lu Q, et al. Overexpression of Shp2 tyrosine phosphatase is implicated in leukemogenesis in adult human leukemia. Blood. 2005;106:3142-9.

14. Zhou X, Coad J, Ducatman B, Agazie YM. SHP2 is up-regulated in breast cancer cells and in infiltrating ductal carcinoma of the breast, implying its involvement in breast oncogenesis. Histopathology. 2008;53:389-402.

15. Maacha S, Anezo O, Foy M, Liot G, Mery L, Laurent C, et al. Protein tyrosine phosphatase 4A3 (PTP4A3) promotes human uveal melanoma aggressiveness through membrane accumulation of matrix metalloproteinase 14 (MMP14). Invest Ophthalmol Vis Sci. 2016;57:1982-90.

16. Wiener JR, Hurteau JA, Kerns BJ, Whitaker RS, Conaway MR, Berchuck A, et al. Overexpression of the tyrosine phosphatase PTP1B is associated with human ovarian carcinomas. Am J Obstet Gynecol. 1994;170:117783.

17. Wang J, Liu B, Chen X, Su L, Wu P, Wu J, et al. PTP1B expression contributes to gastric cancer progression. Med Oncol. 2012;29:948-56.

18. Hoekstra E, Das AM, Swets M, Cao W, van der Woude CJ, Bruno MJ, et al. Increased PTP1B expression and phosphatase activity in colorectal cancer results in a more invasive phenotype and worse patient outcome. Oncotarget. 2016;7:21922-38

19. Bollu LR, Mazumdar A, Savage MI, Brown PH. Molecular pathways: targeting protein tyrosine phosphatases in cancer. Clin Cancer Res. 2017;23:2136-42.

20. Pisamai S, Roytrakul S, Phaonakrop N, Jaresitthikunchai J, Suriyaphol G. Proteomic analysis of canine oral tumor tissues using MALDI-TOF mass spectrometry and in-gel digestion coupled with mass spectrometry (GeLC MS/MS) approaches. PLoS One. 2018;13:e0200619.

21. Yu ZH, Zhang ZY. Regulatory mechanisms and novel therapeutic targeting strategies for protein tyrosine phosphatases. Chem Rev. 2018;118:1069-91.

22. Julien SG, Dube N, Read M, Penney J, Paquet M, Han Y, et al. Protein tyrosine phosphatase $1 \mathrm{~B}$ deficiency or inhibition delays ErbB2-induced mammary tumorigenesis and protects from lung metastasis. Nat Genet. 2007;39:338-46.

23. Liu H, Wu Y, Zhu S, Liang W, Wang Z, Wang Y, et al. PTP1B promotes cell proliferation and metastasis through activating src and ERK1/2 in non-small cell lung cancer. Cancer Lett. 2015;359:218-25.

24. Scott LM, Lawrence HR, Sebti SM, Lawrence NJ, Wu J. Targeting protein tyrosine phosphatases for anticancer drug discovery. Curr Pharm Des. 2010; 16:1843-62.

25. Loo JA, Yan W, Ramachandran P, Wong DT. Comparative human salivary and plasma proteomes. J Dent Res. 2010;89:1016-23.

26. Balogh GA, Mailo DA, Corte MM, Roncoroni $P$, Nardi $H$, Vincent $E$, et al Mutant p53 protein in serum could be used as a molecular marker in human breast cancer. Int J Oncol. 2006;28:995-1002.

27. Solomon H, Dinowitz N, Pateras IS, Cooks T, Shetzer Y, Molchadsky A, et al. Mutant p53 gain of function underlies high expression levels of colorectal cancer stem cells markers. Oncogene. 2018;37:1669-84.
28. Patil WW, Tayade MB, Pingale SA, Dalvi SM, Rajekar RB, Deshmukh HM, et al. The p53 breast cancer tissue biomarker in Indian women. Breast Cancer (Dove Med Press). 2011;3:71-8.

29. Soragni A, Janzen DM, Johnson LM, Lindgren AG, Thai-Quynh Nguyen A,

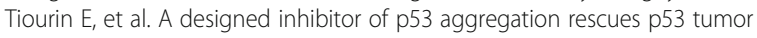
suppression in ovarian carcinomas. Cancer Cell. 2016;29:90-103.

30. Huang K, Chen L, Zhang J, Wu Z, Lan L, Wang L, et al. Elevated p53 expression levels correlate with tumor progression and poor prognosis in patients exhibiting esophageal squamous cell carcinoma. Oncol Lett. 2014;8:1441-6.

31. Samowitz WS, Curtin K, Ma KN, Edwards S, Schaffer D, Leppert MF, et al. Prognostic significance of p53 mutations in colon cancer at the population level. Int J Cancer. 2002;99:597-602.

32. Molina-Vila MA, Bertran-Alamillo J, Gasco A, Mayo-de-las-Casas C, SanchezRonco $M$, Pujantell-Pastor $L$, et al. Nondisruptive p53 mutations are associated with shorter survival in patients with advanced non-small cell lung cancer. Clin Cancer Res. 2014;20:4647-59.

33. Zaky AH, Elsers D, Bakry R, Abdelwanis M, Nabih O, Hafez R, et al. Prognostic value of accumulative expression of COX-2 and p53 in small and diffuse large B cell lymphoma. Pathol Oncol Res. 2019:26:1183-90.

34. Poeta ML, Manola J, Goldwasser MA, Forastiere A, Benoit N, Califano JA, et al. TP53 mutations and survival in squamous-cell carcinoma of the head and neck. N Engl J Med. 2007;357:2552-61.

35. Sano D, Xie TX, Ow TJ, Zhao M, Pickering CR, Zhou G, et al. Disruptive TP53 mutation is associated with aggressive disease characteristics in an orthotopic murine model of oral tongue cancer. Clin Cancer Res. 2011;17: 6658-70.

36. Peltonen JK, Vahakangas KH, Helppi HM, Bloigu R, Paakko P, TurpeenniemiHujanen T. Specific TP53 mutations predict aggressive phenotype in head and neck squamous cell carcinoma: a retrospective archival study. Head Neck Oncol. 2011;3:20.

37. Gross AM, Orosco RK, Shen JP, Egloff AM, Carter H, Hofree M, et al. Multitiered genomic analysis of head and neck cancer ties TP53 mutation to 3p loss. Nat Genet. 2014;46:939-43.

38. Osman AA, Neskey DM, Katsonis P, Patel AA, Ward AM, Hsu TK, et al. Evolutionary action score of TP53 coding variants is predictive of platinum response in head and neck cancer patients. Cancer Res. 2015;75:1205-15.

39. Alexandrova EM, Yallowitz AR, Li D, Xu S, Schulz R, Proia DA, et al. Improving survival by exploiting tumor dependence on stabilized mutant p53 for treatment. Nature. 2015;523:352-6.

40. Parrales A, Iwakuma T. Targeting oncogenic mutant p53 for cancer therapy. Front Oncol. 2015:5:288

41. Mattoscio D, Chiocca S. SUMO pathway components as possible cancer biomarkers. Future Oncol. 2015:11:1599-610.

42. Bergman PJ. Canine oral melanoma. Clin Tech Small Anim Pract. 2007;22: $55-60$.

43. Owen LN. Head and Neck. In: Owen LN, editor. TNM Classification of Tumours in Domestic Animals. 1st ed. Geneva: World Health Organization; 1980. p. 21-5.

44. Henson BS, Wong DT. Collection, storage, and processing of saliva samples for downstream molecular applications. Methods Mol Biol. 2010;666:21-30.

45. Lowry OH, Rosebrough NJ, Farr AL, Randall RJ. Protein measurement with the Folin phenol reagent. J Biol Chem. 1951;193:265-75.

46. Johansson C, Samskog J, Sundstrom L, Wadensten H, Bjorkesten L, Flensburg J. Differential expression analysis of Escherichia coli proteins using a novel software for relative quantitation of LC-MS/MS data. Proteomics. 2006;6:4475-85

47. Thorsell A, Portelius E, Blennow K, Westman-Brinkmalm A. Evaluation of sample fractionation using micro-scale liquid-phase isoelectric focusing on mass spectrometric identification and quantitation of proteins in a SILAC experiment. Rapid Commun Mass Spectrom. 2007;21:771-8.

48. Perkins DN, Pappin DJ, Creasy DM, Cottrell JS. Probability-based protein identification by searching sequence databases using mass spectrometry data. Electrophoresis. 1999;20:3551-67.

49. Thomas PD, Campbell MJ, Kejariwal A, Mi H, Karlak B, Daverman R, et al. PANTHER: a library of protein families and subfamilies indexed by function. Genome Res. 2003;13:2129-41.

50. Bardou P, Mariette J, Escudié F, Djemiel C, Klopp C. jvenn: an interactive Venn diagram viewer. BMC Bioinformatics. 2014;15:293.

51. Szklarczyk D, Santos A, von Mering C, Jensen LJ, Bork P, Kuhn M. STITCH 5: augmenting protein-chemical interaction networks with tissue and affinity data. Nucleic Acids Res. 2016:44:D380-4. 
52. Waterborg JH, Matthews HR. The Lowry method for protein quantitation. Methods Mol Biol. 1984;1:1-3.

53. Aldridge GM, Podrebarac DM, Greenough WT, Weiler IJ. The use of total protein stains as loading controls: an alternative to high-abundance singleprotein controls in semi-quantitative immunoblotting. J Neurosci Methods. 2008; 172:250-4.

\section{Publisher's Note}

Springer Nature remains neutral with regard to jurisdictional claims in published maps and institutional affiliations.

Ready to submit your research? Choose BMC and benefit from:

- fast, convenient online submission

- thorough peer review by experienced researchers in your field

- rapid publication on acceptance

- support for research data, including large and complex data types

- gold Open Access which fosters wider collaboration and increased citations

- maximum visibility for your research: over $100 \mathrm{M}$ website views per year

At BMC, research is always in progress.

Learn more biomedcentral.com/submissions 